\title{
日本のエネルギと原子力
}

\author{
一一昭和 30 年 1 月 22 日新春特別講演会—
}

資源調查会副会長 東大教授 安 芸 晈 一

要旨： わが国に指けるェネルギの現状について，特に電力問題について詳細に述べた。炎発 麗に打ける石炭依在度は今後どの程度保証できるであるらか, しかも熱效率が低いので, 將来はダ ム方式の水力発電をさらに開発すべきである。目下 5 力年計画に従つて着々と開発が進められてい るが，地形，貯水池の容量，湖底村の移転問題などによるコスト高が大きな影響をもたらしてい る。

一方，將来ますますエネルギ需要は塯大して行くが，わが国における必要エネルギの磪保のため には, 最近の弪界の流れに入つて行かねばならない。ことに地熱, 太陽熱, 原子力の問題を考えて 行く必要老感じる。

原子力は社会的に，技術的に困難性はあるが，人類として関心を持つべきではなかららかまた 如何なるェネルギでも合理的に使いとなせるよらにすべきではなかろらかと結論した。

昭和29年度の予算に原子炉築造のための補助費とい う項目があげられたのには，われわればかりではなく 一般の夺も警かれたこと之思う。とにかく準備とい うよりもほとんど事態がわからないために，どうする にも方法がなく，予算補助という形で計上されたので 西るが，その後いろいろ討議された結果，これは原子 炉築造に関する調查についてということになつて，経 済審議庁あるいは通産省にそれぞれ準備会のようなも のができ，昨年の暮には十数名の方々が海外における 事情の調査にでかけられた。この予算が国会を通過し てからはいろいろのところでいろいろな議論が出てお り，現在はそれぞれの分野において統一されている状 態ではなく，まだこの動きについて釈然としていない 点もあることは確かであり，今日のような国際情勢の もとでは問題になることは確かであると思う。しかし 今日すでに原子力を平和的な目的に使うという意味で 検討が進められていることは事実であつて，1952年の 第一回のアメリカの会議, ナショナルインダストリア ル・コンフェレンスでは原子丹利用の問題, 主として アィソトープの利用が討議され，次いで1953年10月は じめに第二回目が開かれ，この時の討議ではこれを動 力にどうして使うかということが最大のテーマであつ た。これはウランを燃料とした発電所ということにな り，技術的には非常に難しい問題をもつている。たと えばウランの棒を作るのはどうするのか, 減速装置, 冷却装置はどうしたらよれのかなどという技術的な間
題が討議される段階に達していた。今日，イギリスや アメリカで 5 万万kW の原子炉がつくられていると いうことも聞てているが，アメリカ，イギリス，听 ヤでは非常に進んでおり，カテダ，フランス，フルウ エー，デンマーク，スエーデンでも原子炉がつくら れ，その研究も進められている。

このように各国でをれでれ研究が進められている が，今日の見通しでは，一般用に使うということには まだ多くの問題を持つていると思われる。コンマーシ ヤルに使うには価格の問題が非常に大きいし，これを 利用する研究についても，十分民間の間に大つていな い現状であろう。今日一般用としては緊急な問題に当 面しているというわけではない。しかし現実に原子力 の利用というものが，この方向に進んできているとい うのが現在の状態であつて，将来十分な可能性があ. る。たとえばアメリカでは1953年の春に，民間の会社 が原子力委員会の依頼をうけて原子力発電所の設計を 行い，推定価格を出しているが，てれによると電子力 発電所の発電原価は，原子炉の形式でいろいろ相違す るが，20万kW 程度のものを造るとして大体 $\mathrm{kWh}$ 当 り 12 ミル内外といつている。今日では石炭を楚く火力 発電所の発電原価が 6 ミル内外であるから, その二倍 程度になつている。これは一番はじめの試算で, あと 10年, 20年の間には火才発電所より安くできるのでは ないかと思われるといつている。それで将来はこれを 使うという方向に進んでいるわけであり，日本でも突 
然この問題がおきたわけで，これが将来ぎんな形での びてくるか，ぞんな面でどんな役割が出てくるのかを 考えてみたいと思う。

日本の主なエネルギ源は石崖と水力とであり，これ が全体のエネルギ消費の $80 \%$ 程度に達しておりりここの 二つがどうなるかということが将来の日本のエネルギ がどうなるかということを推定させるるので西る。 すなわち日本の石炭や水力はどんな問題をもってい るかということである。今日水力電気は昭和28年を 基集にして 5 カ年計画という形で開登が進められて いるが，28年度には70万 $\mathrm{kW}$ 余りの新設あるいは堌設 をみておりかなりのびをきたしている。しかし一体 何年位開発事業が続けられるだろうかということが問 題である。日本の水力電気は明治 23 年に京都の琵琶湖 の疏水を利用したのが最初で，今日では 770 万 $\mathrm{kW}$ 程、 度の設備をもつている。大部分の水力発電所はいわゆ る流れ込み式という形式をとつておりこれは簡単な 設備で河をしめきり水をひき大れて，割合容易に降落 差を得られるというものであり, 従つて割合安く電力 を得ることができる。しかしこの方式では出少は河川 の自然流量に支配されるのであり, 最初は渴水量を基 準にして 360 日程度の水量学目標にしていたのである がそそれで水力電気を十分睄うことができた。ところ が次第に需要が增えてくるに従つて，渴水量を基準に したのでは流水の大部分を捨てることになり，これを もう少し利用度を上げていこうということから設備学 大きくしはじめ, 昭和の中頃までには渴水量の $2 \sim 3$ 倍程度の設備旅沙るようになつた。そうすると渴水 時即ち水の少くなつた期節には出力が減るわけであり それを補給するという目的で火力発電所が続いて造ら れた。すなわちはじめに水力がのびて物き，続いて火 カが発達してきた。要するに水力の設倩が大きくなる につれて，尖頭負荷時とか渴水期之かの電力を補給す るために火力が設けられたのである。最近では水力の 設備はさらに大きくなり，渴水量の 4〜5 倍とかの設 備にしているので沢山の水を使うことになる。それで $\mathrm{kW}$ 注相当大きなものが得られることになるが， $\mathrm{kWh}$ の方は一寸した貯水池觉造つた場合ととれ程変らない ことになる。出少は変らない位に水の量赏あげてくる わけであるが，出力の谷は大きくなり，これをさらに 補填するという形でやってきたのである。水力の開発 が進むにつれてこれがなかなか補填できなくなり今日 のような問題が抢きてきたのである。

日本は豊富低廉な電力があるといわ机てきたのであ るが，今日停電が起るとか毎年電気料金の值上りが起
きてくるというわけで，はじめの話と大分違うのでは ない办と一般に考えられているほどでる。昭和 28 年 に竣功した水力発電所は約 70 数万kW であり,これは 5 カ年計画の第一年のものであるが，この計画によれ ば電源開発の量は水力が 370 万kW，火力が 140万.kW で，全部が竣功した場合，水力の発電原価は 3 円60銭 位, 火力の場合では 5 円30銭位, 両方併せて 4 円 30 銭位 になつている。昭和 27 年の基準では $1 \mathrm{kWh}$ の水力の発 電原価が 1 円05銭, 火力が 7 円 27 銭, 両方併せて 2 円 36 銭である。また昭和28年に竣功したものの建設費は一 番安いもので $\mathrm{kW}$ 当り 7 8 万円程度, 高いもので18〜 19万円程度, 平均 10〜11万円である。昭和5〜 10年頃起 設されたものは $\mathrm{kW}$ 当り 350〜450 円程度であり，今 日竣功しているものとほとんど変らない。これは技術 的に進歩しているので，建設費が安くつくという努力 も認められるが，大体あまり違つてはいない。ただ気 になるのは以前は殆ど大きな巾がなかつたのが最近で はこれが非常に大きくなつたということであつて，7 万円より19万円程度にまで故んでいる。これはがム觉 もつている発電所が割合に高いということである。も つともダムをつくることにより下流に在る既設発電所 が利益を得るので, 爷和程高くはないのだともい光る。

そこで何故公劳つくらねばならないかというと前 述の上うに水の利用率が次第に増してきたからで西 る。たとえば今たでのような水力の建設費, 火力の建 設費, さらに石炭の価格が戦前と戦後では大分变つて きたし，火力は今日では大体年間 900 万 $\mathrm{t}$ 程度の石炭 を使つているが，これは日本での最大の石炭消費量で あり，将来にここな゙供給できるかということである。 ぞれだけ電力が石炭に期待できるかというとこれを 無闇に大きくすることは難しいのであつてなる心゙く水 で処理してゆきたい。それにはどうしてもダムをつく り，水学調整していくということになる。日本は地形 が急峻で雨水に恵まれているがこれは地形が地質的 にいろいろ変動然受けているのだといえる。日本列 島が大陸のはしにありこれを切つて断面をつくつ てみると，大洋に向って素睛らしい䋗をつくつている わけであり, 従つて妙なストレスがかかつているとい うことが考元られる。さらにこの上に火山作用学受け ているのであるから，日本の地形は非常に細かく，か つ複雑になつている。大陸で発電の仕事をしている人 達が日本の水力床ていうことは，とうも日本の土ン ジニヤは大胆だ，我々はこんな所に思いきつて大きな コン゙クリートダム䒹つくるということは一寸こわい気 がするといっている。昨年の春に国際連合の極東つ 
ジア経済委員会の水資源開発会議が東京で開かれた 際アメメカやロシャの技師達もとのようなことをい つていた。しかるに戦後大きながムがあちこちで建設 されているし，5 カ年計画にも相当入つていて,水力だ けで需要に応えられるように目論まれている。電力の 外に洪水調節のこと老己考光，多目的のダムが全国で 40個所あまりもつくられている。これらの様子をみる とやっている中に段々之費用が嵩んでく当。多くの場 合岩盤が面白くなく，はじめに考えたよりも掘謷量が 增え，結局工事費が3〜 割もふえている実例がある。 もう一つは，地形が急峻なために䝪水池学つくつても その容量が比較的小さいことである。䝪水池をつくる に要するコンクリートの量で貯水池の容量を割つてみ ると，アメリカでは $1,000 \mathrm{~m}^{3}$ が普通であるが，日本で はその $1 / 10$ 位であって $100 \mathrm{~m}^{3}$ にすざない。日本の雨 は年間 $1,600 \mathrm{~mm}$ 程度であり, 少い所で $1,000 \mathrm{~mm}$, 多 い所では 4,000 mm 学こえるところもある。これは世 界的にみて恵まれているとい光るしかしさらにこれ を分析してみると，太平洋岸と日本海岸とでは異り， また日本の多くの部分は台風の影響学うける。台風に よる雨が全雨量の約30〜 40\%でありここの種の雨は大 体 3〜4 回位の台風でもたらされ，一回 10〜15 時間程 度であるから，比較的短い間に全体の30４0\%の雨が ふるわけである。量からみると非常に大きいのである が，これを比較的小さな池で調節するということは容 易ではなく，余程確かな降雨の予測がたたない限り調 整は困難である。日本の䀧水池の容量は最大のもので 約 1 億 $\mathrm{t}$ であるが，ての流域に降つた一つの洪水で全 部䝰められるというものではなく，その半分以下ある いは30\%程度というのさえ西るわけで調整は難しい。 さらに今日最も問題となつていることは, 池觉つくつ た場合，これに埋没する人家や耕地觉どうするかとい うことであり，その補償費が非常に高くなつているか らである。昭和のはじめ頃までにつ々られたダムをみ ると殆き人家や耕地のない処であつたが，その後は次 第にふ元て昭和10年頃では100戸位の家，100町歩位の 耕地というのが普通であつた。最近になると非常にふ えて 400〜3,500户の人家を移転せねばならないような 場合もある。以前はその人達の行先も容易であつたし また買上げ代金で生活することが可能であったが，今 日では難しい間題であり，今後の生活の保障究しなけ ればならない。以前はこの費用がダム建設費の 2 3\% であつたが最近では20〜30\%に達し，今考えていると ころでは建設費を上廻るような例さえ見受けられる。 水力電気にがムをつくることがふえてくれば費用がか
さんでくるのはこのことからも当然である。しかし， 今日ではどうしてもダム存造りたいという状態であ り, 日本の包藏する水力を 2,200 万 $\mathrm{kW}$ 程度とみて, 今日開発されたものは約 770 万kW，35\%位である。 今後残された所は比較的條件の良くない所, 地質的に 問題になる所, 非常に奥地で建設に困難な所, 流れ込 み式の発電形式では能率が悪い所, 洪水が問題とな゙ る所とかであり，電力の開登节考えるとどうしても 今後はダムの製造が要求されるわけである。石炭觉だ く方の電无ではこの価格が 7 月余りの発電原価になつ ており，5 カ年計画では 5 円余りとかえつて安くなつ ている。現在石炭をたいている発電所の熱効率は約 19 \%であり，今日では非常に高い能率，30\%をこえるも のが建設されている。大体は高温で高圧のボィラから 発電機と変つてきている。日本でも次第にとういうも のがつくられているが，熱効率の高い発電所では二二 ットが関係してどうしても 25 万 $\mathrm{kW}$ 程度の発電所にな るし，こういう発電所では今までの様に短時間運転を やるということが困難である。今までのシステムから いえば，日本の火力は大体電力需要の山圭うめたり谷 をうめたりして補給するという運転方法をとつてきた のであるが，このような短時間運転をするというこ とが難しくなつてくる。火才発電学十分生かして效率 の高いものにすると，むしろ石炭をべースとする傾问

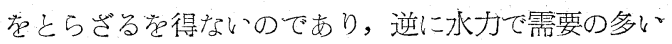
処萑補うという形になる。今日までの水力と火力との 組合せの方式は日本に特異なものであつて，日本の條 件を非常にうまく利用してきたものであり，その意味 で豊富低廉な電力といわ礼てきた。しかし今日の傾向 英みるとやはり世界的な一般の流れに入つてきて拈 りすでに今までの形式でェネルギ觉供給するこ とが非常に難しくなつてきているので，電力につい ても何か新しい組合せというものが考元られるので はないか。かえつて日本の今までいわれていた條件が 逆に衝くという事態がくるのではないかと思う。これ は石岩についてもい劣ることであつて，石炭が高いの は金利が負担になつているとか，税金に開題があると か, または石炭の本質的な問題から, 現在の経営方式 がとられなければならないのかなどといわれておりこ れも難しい問題である。

以上は日本のエネルギ資源が今日当面している問 題学簡単に述へたたの゙あるが，さららわれわれはこの 困難な問題を今後どう展開して行かねばならないのか ということである。これには経済審議庁で立案されて いる昭和 40 年の構想というものがあり，また 6 カ年訫 
画というものが出されている。これは将来日本の人口 增加を予定し，その人口が完全に働き得る機会を与元 るにはどれだけの産業の規模を持たねばならないかと いうことであって，6 カ年計画によれば昭和35年には 国の総生産高を 8 兆 8,000 億とあげねばならない。こ れは今日の 2 倍以上の生産であり，そのためにはぞの ような原料がいるのか，それに要するェネルギの量が いくらになるのかということを知らねばならない。人 ロが 1 億程度になつた場合には $6,500 \mathrm{cal}$ の石炭に換 算して 2 億 $\mathrm{t}$ 程度のものがいることになり，倍近い土 ネルギを供給しなければならないであろう。われわ れは水力が $35 \%$ しか開発されておらず，開発可能な ポテンシャルはまだ 1,000 万 $\mathrm{kW}$ 程度あることを知っ ているし，また昭和 40 年頃には 5,700 万 $\mathrm{t}$ 位の石炭を 出とうということにもなつている。供給可能量は一寸 試算したところで 1 億 6,000 万程度といわれている。 しかし，今日でも多くの間題があるのにこれを偣增し てそれだけにすることは余程考えなければならない。 しかもな抢 4,000 万程度足りないわけである。またわ れわれがどんな効率でエネルギを実際に使つている か，たとえば電気はもつともよく使われているかとか 石炭は最もよい目的に使われているかとかいう問題で ある。アメリカやイギリスの例をみても，ここ20〜30 年間ほとんど一人当りの消費量は変つていない。しか も生産は非常にふえてきていることに関心を执わなけ ればならない。もち万ん新しくェネルギの量学増やし てゅくということもやらねばならないしこれをどう 調整していくかということも考えねばならないし，工 ネルギの新しい構想を考元直さねばならないのも事害 であり，それらの解決には困難な多くの問題がある。 同時にまたこれらのエネルギをどういう風に使つてい か杖ばならないかということを考えると共に，それぞ れについてできるだけ能率の上る使い方を考えねぱな らない。今後10〜15年はどうにかやっていけるかもし れないがその先は一寸難かしいという状態ではなから うか。水力や火力発電にしても, 長い間一つの流れの 中で建設が進められているので，これを新しい組合せ にもつてゅくことは問題であり，使い方にしても適性 な使い方をしてゆくのには問題がある。

今日，炭価の高いのが問題になつているが，これを 本当に安くしてできるだけ国際価格に近づけてゆく。 日本の経済は独りではやってゅけないから自給自足的 な考え方では片附けていけない。むしろそういう方法 をとるとすればわれわれの生活を下げざるを得ない。 そうするには物の生産をできるだけ国際価格で生産し
ていかなければならず，炭価の高いのが問題となる。 石炭の合理化というものは素人の考えでは，石炭を掘 るための設備の合理化をすすめる方がいいのか，また は使い方の方に問題があるのかと思われる。今日市販 炭は出炭の $60 \%$ 程度で残りの $40 \%$ またはとれ以上が殆 ど使われていない。電気にしても, 日本の電気が最も 有効に使われているかというと考えざるを得ない。た とえば電力炎使つて水の分解をやり水素をとるという 方法节今後も続けていってよいのであろうかというの である。こんなところに非常に難しい問題がある。い ろいろのェネルギ源の組合せを考えてさらに適性な使 い方を考えなりればならない。将来水力が $1,000 \mathrm{~kW}$ 位開発できるとか，石炭が 5,700 万 t 位增産できると か言つても，その価格がどうなるかは疑間を持たざる を得ない。今後 2 倍程度のエネルギを供給しなけれぱ ならないということになると、これを便いこなしてゅ くためにも大いに検討しなければならない問題があ る。恐らく工業国と言わ机ている国々で今日持ってい るエネルギがこれほど問題をもつており，さらに後 について解決しなければならない大きな問題を持ちな がら工業生産を進めていかなければならないという国 は，日本の他にはそれほど無いのではなかろうか。そ うするとわれわれは今持つているものを有效に使うと 同時に，今迄使つていなかつたものを使つてゅくとい うことを考えねばならない。地熱の問題や太陽熱の問 題もあるが，ここで原子力というものをも考えねばな らないと思う。西と10〜20年経つと原子力は技術的に も経済的にも十分他のエネルギに匹敵できる範囲内 で，供給できるだろうをいわれているのであつて，十 分考えねはなならいと共にまた非常に難しい問題, 技 術的のみならず社会的にもいろいろの問題がある。技 術的な面からみても放射能を带びた灰をどう処理して ゆくかということもまだきまつてはいない。しかも国 際的問題の抢きている中でこれをやつていこうという のである。私はこの問題については世界各国が動いて いるようにできるだけ早く研究を進めて加かばなな ないと思ている。ここ10〜10数年経てば，原子力燃料 についての国際管理的な見通しが持てるのではないか と思う。その時にはわれわれも十分これを使いこなし 得るように設備をして打か叔ばならない。日本の将来 の状態から考えて，あらゆる可能なエネルギをどんな ものでも使いこなし得る体制を持つということを考え ねばならない。

われわれに与えられている物はえれぞれ地域的な特 性をもつているが，それを最も適性に使いこなし得る 
ような状態を常に研究しなければならない。しかもと れを国際的な流れの中で，常に関心を持ちながら検討 せねばならない。経済審議庁の昭和 40 年の構想に示さ れているように，10年以内に少くともわれわれの生産 を2倍にしなければ生活は下らざるを得ないというう けであるから，これが可能かどうかということは恐ら く与无られた原料をわれわれが技術的に使いこなし得 るかどうかということにかかつているのである。非常
に難しい問題もあるが，これを可能にしなければ，今 後は経済の循環がそれだけの高さで成立しないことに なるのであり，特にわれわれの産業活動のベースにな つている土ネルギの間題, その原料をどういう風にし てわれわれの生産活動の下に要求に応えられるように してゆくかということは，私自身も非常に関心をもつ ているわけであり，是非この点について新しい分野を 切拓いて頂きたいと念願するものである。

\section{Japanese Energy Resources and Atomic Power}

by Kōichi Aki,

(Professor of Tokyo Univ., The Resources Council, Prime Ministry)

SYNOPSIS :-The author described on the situations of energy in Japan, especially those of electric power problem in detail.

It is of our great concern that how long thermal power may depend upon coal. We cannot expect it much on coal, and what is worse, its thermal efficiency is low. The author emphasized future aspect on development of water power by means of damsystem. From this view-point the endless development is being made under five years' plan of electric power development. We are, however, obliged to face the undesirable problems in water power development such as those on land, capacity of reservoir and compensation which excert great influence upon raising cost.

On the other hand, future energy demand is making increase more and more, and it is expectable that Japan acts in concert with the current of the world in order to ensure necessary and sufficient energy. Thus, it is a natural consequence that we are concerned with the geotherm, the solar energy and the atomic power.

The problem on atomic power has its social and technical difficulty, nevertheless we should be interested in it. The author concluded whatever energy should be utilized efficiently and rationally.

U.D.C. $622.33(52)$

\section{石 炭鉱 業の將 来}

\section{一一昭和30年 1 月 22 日新春特別丵演会——}

\section{貝島炭礦株式会社 管理部 黑 田 三 郎}

要旨： 石炭鈗業々聍炭の激塯, 金融危機, 労組問題なぞにより重大な危機に直面している。てれ らの対策として種々实施されているが，炭鉱企業が他産業と異なる種々の惡條件に制約されているた

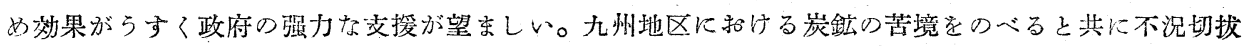
け筑, 炭価切下げに対する堅坑開発の效果, 実績なぞについて解說し, さらに今後の炭鈗経営上の問 題として, 低炭価, 品啠向上和よで安定生産を目途とした竪坑方式による合理化, 石炭鉣業臨時措置

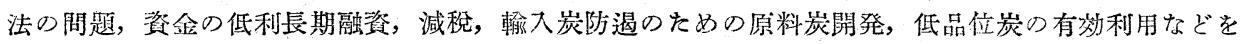

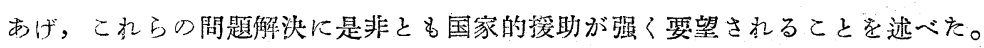

